\title{
ЮРИДИЧЕСКАЯ ПРИРОДА ПОРУЧЕНИЙ ПРЕЗИДЕНТА РФ ГЛАВАМ СУБЪЕКТОВ РФ
}

\author{
(c) 2021 Зайцева Елизавета Евгеньевна \\ студент-магистрант \\ Юридическая Школа ДВФУ, Россия, Владивосток \\ E-mail: zalizaveta98@mail.ru \\ (c) 2021 Баранова Вероника Алексеевна \\ студент-магистрант \\ Юридическая Школа ДВФУ, Россия, Владивосток \\ E-mail: nikazlaya97@mail.ru
(C) 2021 Кешишян Александра Вагаршаковна
студент-магистрант
Юридическая Школа ДВФУ, Россия, Владивосток
E-mail: alekasndrak@mail.ru

Вопрос о правовой природе поручений главы государства, в том числе, поручений Президента Российской Федерации главам субъектов России, является достаточно дискуссионным. Отсутствует единообразное понимание как понятия и правового статуса такого рода поручений, степени формализации, так и юридической силы, осуществления контроля за их конституционностью. В настоящей статье рассматривается юридическая природа поручений Президента Российской Федерации сквозь историческую призму и сравнительного анализа поручений и нормативно правовых актов.

Ключевые слова: поручения президента, юридическая природа поручений, нормативно-правовой акт, Конституция РФ, свойства поручений Президента

Несмотря на широкое применение института поручений Президента Российской Федерации на практике, в Конституции Российской Федерации он прямо не предусмотрен [1]. Именно поэтому в основе исследования юридической природы поручений Президента России главам субъектов Российской Федерации лежат, прежде всего, научные исследования, существующие подходы и концепции, а также практика применения данного института. Вместе с тем, следует учитывать изменения, внесенные в Конституцию Российской Федерации на основании Закона РФ о поправке к Конституции РФ от 14.03.2020 № 1-ФКЗ «О совершенствовании регулирования отдельных вопросов организации и функционирования публичной власти» [2].

Так, ст. 113 Конституции РФ, посвященная деятельности Председателя Правительства Российской Федерации и его персональной ответственности перед главой государства, прямо указывает на существование такого особого акта, как поручение Президента: «Председатель Правительства Российской Федерации в соответствии с Конституцией Российской Федерации, федеральными законами, указами, распоряже- ниями, поручениями Президента Российской Федерации организует работу Правительства Российской Федерации» [3].

Итак, внесенные в Основной закон государства изменения впервые, на самом высшем, конституционном уровне, определили такой акт, как «поручение Президента Российской Федерации». Таким образом, наряду с закрепленными в ч. 1 ст. 90 Конституции РФ указами и распоряжениями Президента Российской Федерации действуют и некие «поручения», правовой статус которых представляет большую актуальность.

А.Н.Артамонов в своих работах писал, что «...сами по себе поручения Президента РФ не являются какой-либо новеллой на отечественном правовом поле» [4]. Появление указанных актов связывают с периодом «указного нормотворчества», характерным для 90-х гг. ХХ в., когда имелось достаточно жесткое противостояние между парламентом и главой государства. 6 ноября 1996 года Б.Н.Ельциным, Президентом Российской Федерации, был издан Указ № 1536, в соответствии с которым приняты меры по повышению исполнительской дисциплины органов исполнительной власти по выполнению поруче- 
ний Президента, в том числе, должностных лиц федеральных органов исполнительной власти и соответствующих органов в субъектах РФ [5]. С того времени необходимость издания подобных поручений не потеряла своей актуальности, более того, можно говорить о повышении нормативной регламентации института президентских поручений.

В соответствии с Порядком исполнения поручений и указаний Президента Российской Федерации, утвержденным Указом Президента РФ от 28 марта 2011 г. № 352, поручения и указания Президента РФ даются в целях реализации его конституционных полномочий [6]. Поручения Президента России содержатся в его указах и распоряжениях, а также в директивах или оформляются в установленном порядке на бланках со словом «Поручение». Поручения Президента России могут оформляться в виде перечней поручений Президента РФ.

Следует отметить, что в некоторых субъектах Российской Федерации приняты специальные нормативные акты, регламентирующие исполнение поручений Президента РФ органами государственной власти субъекта (например, в Свердловской области [7], Ямало-Ненецком автономном округе [8]).

Поручения Президента РФ являются довольно распространенными документами, характерными для отечественной системы государственного управления, и издаются достаточно часто. По официальным данным в 2020 году Президентом России было издано более 900 поручений (с 1 января 2020 г. по 24 октября 2020 г.) [9].

В науке вопрос о правовой природе президентских поручений единообразно не разрешен. Я.Ю.Старцев указывает, что поручения Президента РФ - акты с неопределенным статусом, поскольку, с одной стороны, они не являются правовыми актами и, с другой стороны, не являются актами нормативными, «их выполнение обязательно лишь для адресата,- но при их исполнении могут приниматься как административные, так и нормативные акты» [10]. С позицией автора относительно не признания поручений Президента правовыми актами вряд ли можно согласиться. Действительно, «между взаимоисключающими терминами «правовой» и «неправовой» не существует чего-то иного. Представляется, что отнесение каких-либо управленческих актов главы государства к неправовым недопустимо...» [11].

Исходя из общей теории права правовые акты органов государства - это официальные документы компетентных государственных органов, направленные на достижение каких-либо юридических последствий [12]. Абсолютно все правовые акты характеризуются следующими общими признаками:

а) государственно-властный характер - они исходят от государства, всегда связаны с его властными полномочиями (поручения Президента Российской Федерации соответствуют указанному признаку);

б) они обязательны для исполнения лицами, к которым они адресованы (в поручениях Президента РФ чаще всего указываются «Ответственные лица», среди которых и главы регионов России - высшие должностные лица субъектов РФ);

в) они влекут определенные юридические последствия, т.е. влияют на права и обязанности субъектов. Конкретный вид и мера ответственности за неисполнение поручений Президента РФ различными субъектами, в том числе, главами регионов России, не предусмотрена. Вместе с тем, следует учитывать все существующие виды юридической ответственности и соответствующие последствия. Отметим также, что еще в 2014 году разработан законопроект о дополнении Уголовного кодекса Российской Федерации новым составом преступления в рамках ответственности за халатность, а именно - халатность, связанная с неисполнением или ненадлежащим исполнением указов, распоряжений и поручений Президента РФ. Предлагалось также ввести административную ответственность за неисполнение должностными лицами, в том числе, поручений Президента России, если только действия не содержат состава преступления. Также законопроект предусматривает расторжение служебного контракта, освобождение от замещаемой должности гражданской службы и увольнение с гражданской службы гражданского служащего в случае однократного грубого нарушения им должностных обязанностей, выразившегося в неисполнении гражданским служащим, замещающим должность гражданской службы категории «руководители», без уважительной причины, указов, распоряжений и поручений Президента РФ [13];

г) они поддерживаются силой государственного принуждения.

Таким образом, поручения Президента России главам субъектов Российской Федерации в полной мере соответствуют всем признакам правовых актов. 
В.Е.Зорькин считает поручения Президента России подзаконными нормативно-правовыми актами. Исследователь пишет о возможности охарактеризовать «...поручения как инструмент реализации полномочий Президента РФ, обладающего такими же юридическими свойствами, как указы и распоряжения Президента, то есть носят подзаконный характер, занимают подчиненное по отношению к Конституции и законам место в иерархии нормативных правовых актов» [14].

Итак, несомненно, поручения Президента Российской Федерации, в том числе, главам субъектов России, относятся к правовым актам. Возникает вопрос об их отнесении к нормативным актам.

Специфика нормативно-правовых актов проявляется в том, что они направлены на установление, изменение или отмену норм права. Нормативно-правовые акты содержат нормы права, распространяются на все субъекты, попадающих в сферу действия, и на множество типичных жизненных ситуаций; имеют долгое, неограниченное по времени действие, таким образом, рассчитаны на повторное и многократное применение.

Рассмотренные признаки нормативноправовых актов для поручений Президента Российской Федерации главам субъектов России не характерны.

Во-первых, президентские поручения адресованы конкретным субъектам (лицам).

Так, поручение Президента Российской Федерации Пр-1726ГС (п.1 б)) адресовано Правительству России и органам исполнительной власти субъектов РФ, которые должны до 01.12.2020 совместно рассмотреть вопрос о модернизации инфекционной службы, включая лаборатории, оснащение медицинских центров в регионах России. Среди ответственных лиц указаны и главы субъектов РФ [15]. Более того, в некоторых поручениях указаны главы конкретных субъектов - так, например, в поручении Пр-1506 (п.2) среди ответственных лиц названы высшие должностные лица субъектов, входящих в состав ДВФО.

Во-вторых, президентские поручения не направлены на множество типичных жизненных ситуаций. Вопросы, на решение которых направлены президентские поручения, касаются практически всех отраслей и сфер государственного управления. В них содержатся прямые указания
Президента РФ по осуществлению каких-либо действий: внесение изменений в законодательство, подготовку и принятие нормативных правовых актов, рассмотрение того или иного вопроса, подготовку и представление предложений по совершенствованию тех или иных управленческих процессов, принятие определенных мер, выделение из бюджета денежных средств, обеспечение выполнения поставленных задач, организацию работы и т.п.

Так, поручение Президента Российской Федерации Пр-1246 (п. 2 а)), за исполнением которого ответственны и главы регионов РФ, предписывает в осенне-зимнем эпидемическом сезоне 2020-2021 гг. предусмотреть возможность дополнительного развёртывания коек, в том числе для лечения больных с осложнёнными случаями гриппа и других острых респираторных инфекций, а также сохранить резерв специализированных коек для лечения больных новой коронавирусной инфекцией (COVID-19).

B-третьих, поручения Президента Российской Федерации, как правило, не рассчитаны на повторное и многократное применение. Многие президентские поручения предусматривают четкий срок их исполнения, вместе с тем, в ряде поручений определены конкретные сроки, а также последующие временные периоды («один раз в полгода», «ежеквартально» и др.). Исполнение поручений зачастую требует длительного времени, соответственно, выделяются и промежуточные сроки для проверки их исполнения, вместе с тем, поручения носят однократный, разовый характер.

Таким образом, поручения Президента Российской Федерации являются правовыми актами, поскольку имеют государственно-властный характер, обязательны для исполнения субъектами, к которым они адресованы, влекут определенные юридические последствия и поддерживаются силой государственного принуждения. Вместе с тем, анализ президентских поручений позволяет сделать вывод о том, что важнейшие признаки нормативно-правовых актов для них не характерны. Поручения Президента России главам субъектов РФ адресованы конкретным субъектам - высшим должностным лицам субъектов России, они направлены на определенные (не типичные) жизненные ситуации в самых разнообразных областях, кроме того, не рассчитаны на повторное и многократное применение. 


\section{Библиографический список}

1. Дробот C.Е. Институт поручений и указаний Президента РФ в свете конституционных целей и функций главы государства // Юридическое образование и наука. 2019. № 6. С. 36.

2. О совершенствовании регулирования отдельных вопросов организации и функционирования публичной власти: Закон РФ о поправке к Конституции РФ от 14.03.2020 № 1-ФКЗ [Электронный ресурс] // СПС «КонсультантПлюс».URL: http://www.consultant.ru/document/cons_doc_LAW_346019/[дата обращения 20.10.2020]

3. Конституция Российской Федерации: принята всенародным голосованием 12.12 .1993 с изменениями, одобренными в ходе общероссийского голосования 01.07.2020 [Электронный ресурс] // CПС «Гарант». URL: https://base.garant.ru/10103000/ [дата обращения 20.10.2020]

4. Артамонов А.Н. Поручение президента как правовой акт // Вестник Брянского государственного университета. 2020. № 3 (45). С. 150.

5. О мерах по совершенствованию организации контроля и проверки исполнения поручений Президента Российской Федерации: Указ Президента РФ от 06.11.1996 № 1536 (утратил силу) [Электронный ресурс] // CПС «Гарант». URL: https://base.garant.ru/136679/\#friends [дата обращения 20.10.2020]

6. О мерах по совершенствованию организации исполнения поручений и указаний Президента Российской Федерации: Указ Президента РФ от 28.03.2011 № 352 [Электронный ресурс] // CПС «Гарант». URL: https:// base.garant.ru/55170890/ [дата обращения 20.10.2020]

7. О Порядке исполнения поручений и указаний Президента РФ исполнительными органами государственной власти Свердловской области: Указ Губернатора Свердловской области от 18.07.2011 № 671-УГ [Электронный ресурс] // СПС «Кодекс». URL: http://docs.cntd.ru/document/453106005 [дата обращения 20.10.2020]

8. Об утверждении Порядка исполнения поручений и указаний Президента Российской Федерации в исполнительных органах государственной власти Ямало-Ненецкого автономного округа: Постановление Губернатора Ямало-Ненецкого автономного округа от 08.04.2013 № 39-ПГ [Электронный ресурс] // СПС «Кодекс». URL: http://docs.cntd.ru/document/473407915 [дата обращения 20.10.2020]

9. Поручения Президента [Электронный ресурс] // Президент России. URL: http://www.kremlin.ru/acts/ assignments/orders (дата обращения: 28.10.2020)

10. Старцев Я.Ю. Поручения Президента РФ: анализ дискреционного инструмента власти [Электронный ресурс] // Академия. URL: https://www.academia.edu/4866184/Поручения_Президента_РФ_анализ_дискреционного_ инструмента_власти (дата обращения: 20.10.2020)

11. Ваньков А.В. Правотворчество Президента США в сопоставлении с отдельными аспектами правотворчества Президента Российской Федерации // Журнал зарубежного законодательства и сравнительного правоведения. 2016. № 6 (61). С. 16.

12. Гайворонская Я.В., Самусенко Т. М. Теория государства и права: учебное пособие. Владивосток: Изд-во Дальневост. ун-та. С. 144.

13. О внесении изменений в отдельные законодательные акты Российской Федерации (в части установления ответственности за неисполнение указов Президента Российской Федерации): Законопроект № 487083-6 (находится в архиве) [Электронный ресурс] // Государственная Дума: официальный сайт. URL: http://asozd2. duma.gov.ru/main.nsf/\%28SpravkaNew\%29? OpenAgent\&RN=487083-6\&02 (дата обращения: 20.10.2020)

14. Зорькин B.Е. Ежегодные Послания Федеральному Собранию Российской Федерации - как акт Президента Российской Федерации // Юридическая мысль. 2011. № 2 (64). С. 37.

15. Перечень поручений по итогам расширенного заседания президиума Государственного совета [Электронный ресурс] // Президент России. URL: http://www.kremlin.ru/acts/assignments/orders/64273 (дата обращения: 28.10.2020) 